\title{
Determination of ETM, Histamine and Mycotoxins in Garba, a Traditional Ivoirian Meal
}

\author{
Adjo Thérèse Anoman ${ }^{1 *}$, Kouamé Mathias Koffi², Kouassi Narcisse Aboua ${ }^{3}$, Marina Koussemon ${ }^{4}$ \\ ${ }^{1}$ Laboratoire Central pour l'Hygiène Alimentaire et l'Agro-industrie, LANADA, Ministère de l'Agriculture, \\ Abidjan, Côte d'Ivoire \\ ${ }^{2}$ Laboratoire de Biochimie et Sciences des Aliments, Université Félix Houphouët Boigny, Abidjan, Côte d'Ivoire \\ ${ }^{3}$ Laboratoire des Sciences de l'Environnement, Université Nangui Abrogoua, Abidjan, Côte d'Ivoire \\ ${ }^{4}$ UFR Sciences et Technologie des Aliments, Université Nangui Abrogoua, Abidjan, Côte d’Ivoire \\ Email: *anoman_therese@yahoo.fr
}

How to cite this paper: Anoman, A.T. Koffi, K.M., Aboua, K.N. and Koussemon, M. (2018) Determination of ETM, Histamine and Mycotoxins in Garba, a Traditional Ivoirian Meal. American Journal of Analytical Chemistry, 9, 245-256. https://doi.org/10.4236/ajac.2018.94019

Received: March 1, 2018

Accepted: April 23, 2018

Published: April 26, 2018

Copyright (c) 2018 by authors and Scientific Research Publishing Inc. This work is licensed under the Creative Commons Attribution International License (CC BY 4.0).

http://creativecommons.org/licenses/by/4.0/

\section{Open Access}

\begin{abstract}
The methods of preparation, conservation and sale of Garba, the traditional Ivorian street meal, abundantly consumed in Côte d'Ivoire, can be exposed to various infections resulting in the poisoning of consumers. The aim of this study was to evaluate the hygienic quality of Garba through the analysis and the determination of certain toxic chemicals. In three hundred (300) samples of Garba collected in four districts in Abidjan, toxic metals (cadmium, mercury, lead), biogenic amine (histamine) and mycotoxins (aflatoxins and ochratoxin A) were detected and quantified using official standardized methods. Different toxics analyzed were present at various levels in the Garba. The mercury, lead, cadmium and histamine levels in the Garba were respectively $0.19 \mathrm{mg} / \mathrm{kg}, 0.19 \mathrm{mg} / \mathrm{kg}, 0.03 \mathrm{mg} / \mathrm{kg}$ and $32.69 \mathrm{mg} / \mathrm{kg}$. The detected mycotoxins included aflatoxins B1, B2, G1, G2 and ochratoxin A, with respective average proportions of $3.44 \mu \mathrm{g} / \mathrm{kg}, 1.90 \mu \mathrm{g} / \mathrm{kg}, 8.07 \mu \mathrm{g} / \mathrm{kg}, 0.56 \mu \mathrm{g} / \mathrm{kg}$ and $0.42 \mu \mathrm{g} / \mathrm{kg}$. The mycotoxins levels in the Garba are higher than the recommended toxic levels, particularly the ones in aflatoxin B1 and G1. This suggests a sanitary risk associated with the consumption of this meal. Consequently, awareness campaigns and training of the Garba sellers in hygiene and a better regulation of this sector by the competent authorities are required.
\end{abstract}

\section{Keywords}

Garba, Toxic Metals, Biogenic Amine, Mycotoxins 


\section{Introduction}

With the grip of sudden and unprecedented urban growth, and an increase in the size of the labor force, the demand for non-traditional services has gained momentum. Street foods are ready-to-eat foods and beverages prepared and/or sold by vendors and hawkers especially in streets and other similar public places [1]. Street foods play an important socio-economic role, particularly in developing countries because they provide accessible and inexpensive food to the populations. Street vended foods are not only appreciated for their unique flavors, convenience and the role which they play in the cultural and social heritage of societies, but they have also become important and essential for maintaining the nutritional status of the populations [2] [3]. Besides offering business opportunities for developing entrepreneurs, the sale of street foods can make a sizeable contribution to the economies of developing countries.

Street foods raise serious safety concerns. Indeed contamination by chemicals and micro-biologicals contributes significantly to the occurrence of food borne illness [4]. The informal food production and marketing system is still strong in most countries, which presents challenges for enforcement of food safety regulations [5]. Street food vending has become an important public health issue and a great concern to everybody. This is due to widespread food borne diseases, due to the mushrooming of wayside food vendors who lack an adequate understanding of the basic food safety issues. Major sources contributing to microbial contamination are the place of preparation, utensils for cooking and serving, raw materials, time and temperature abuse of cooked foods and the personal hygiene of vendors [6]. Among other contamination reasons are conditions on public streets, with increasing levels of pollution due to dust and traffic. Furthermore street food can be contaminated by high concentrations of toxic chemicals such as pesticide residues, heavy metals, mycotoxins or unapproved food additives, such as textile colorants [4].

Food borne illnesses may result from the consumption of food contaminated by microbial pathogens, toxic chemicals or radioactive materials. Several analyses of street food samples showed heavy loads in total coliforms in some cases, and the presence of pathogenic bacteria such as Salmonella spp., Staphylococcus aureus, Clostridium perfringens and Vibrio cholerae [7] [8]. While many food borne diseases may be self-limiting, some can be very serious and even result in death. In Côte d'Ivoire, "Garba" is a popular street food. It is a meal composed of attiéké (cassava meal) of $2^{\text {nd }}$ grade [9], fried tuna, tomato, onion and fresh chili, seasoned with cooking broth. It is expected that, like other street foods, Garba is subject to various infections which can make it unsuitable for consumption. Indeed, its modes of production, preparation, preservation and marketing can be subjected to contamination factors and trigger food borne illness. To date, few scientific data on the hygienicquality of Garba is available.

The present study was undertaken to evaluate the hygienic quality of Garba. In order to achieve this, chemical molecules (heavy metals, mycotoxins, hista- 
mine) that have been recognized to be toxic and as significant sources of food borne illness by the WHO, were investigated in several samples of Garba.

\section{Material and Methods}

\subsection{Material}

\subsubsection{Garba Samples}

The material for this study consisted of the collection of three hundred (300) samples Garba taken from Garba vendors located in four (4) municipalities of the city of Abidjan namely: Abobo, Cocody, Port-Bouet and Yopougon.

\subsubsection{Solvents and Reagents}

Nitric acid 65\% (VWR chimicalsprolabo, France), Oxygenated water 30\% (Carlo Erba Reagent, Espagne) were used for heavy metals mineralization. Trichloroacetic acid (Panareac, Espagne), Orthophtaldehyde (Merck, Germany), $\mathrm{NaOH}$ (VWR Chimicals Prolabo, France), $\mathrm{HCl}$ (Chimie plus Laboratoire, France) were used to prepare samples and histamine determination. For mycotoxin extraction, purification and quantification, Acetonitrile 99.9\% (Prolabo, France), Méthanol 99.99\% (Fischer Chimical/Angleterre), Hydrogénocarbonate de sodium (Prolobo/Belgique), Ultrapure Water (Corning/USA), Tampon phosphate salin PBS (OXOID/Angleterre), Acetic acid, glacial, 99\% (Fluka analytical/Suisse), Toluene 99.9\% (Carlo-chimie/Espagne) were used.

\subsubsection{Apparatus}

Atomic Absorption Spectrophotometer (Spectra AA 110, Varian), High Performance Liquid Chromatograph (Shimadzu LC 20 A Prominence) and High Performance Liquid Chromatograph (Shimadzu LC 20 AT) were respectively used for the analysis of heavy metals, histamine and mycotoxins.

\subsection{Methods}

\subsubsection{Collection and Preparation of Samples}

The collection of samples of "Garba" was done according to the Technical Guide developed by the Cofrac [10]. Samples were transported to the laboratory in coolers. Each sample weighted approximately $200 \mathrm{~g}$ and was made of attiéké (about $140 \mathrm{~g}$ ) and tuna (about $50 \mathrm{~g}$ ) accompanied by tomato, pepper and onion. Prior to the analysis, each sample was mixed and homogenized in a blender (Moulinex, France).

\subsubsection{Analyses of Heavy Metals}

For the examination of metals (mercury, lead, cadmium), the samples were mineralized for 30 to $45 \mathrm{~min}$ in a microwave digester (Milestone) using a nitric acid-oxygenated water mixture in closed containers under pressure. The dosage was done by atomic absorption spectrophotometry (Spectra AA110, Varian). The total mercury was determined by the flameless method according to the cold vapors principle [11] using a hydride generator (VGA 77). The lead and cadmium levels were measured by graphite furnace (GTA, Varian 110) of the 
atomic absorption spectrophotometer on a mineral deposit obtained by sample digestion in a warm concentrated nitric acid-oxygenated water mixture (7/1) according to the AOAC method [12]. A Deuterium lamp was used for the correction of the background noise. For each series of analysis, a digestion of white and a sample of known reference concentration were analyzed to ensure quality control of the results. Readings were made with respect to a calibration curve drawn up in five points for each metal.

\subsubsection{Analyses of Histamine}

The determination of histamine was carried out by high performance liquid chromatography according to the Ifremer method [13]. The extraction was made using trichloro-acetic acid and detection by fluorimetry (RF-10AxL) at $360 \mathrm{~nm}$ and $450 \mathrm{~nm}$ as excitation wavelength and emission respectively after derivation using ortho-phtaldéhyde (OPA). The column used is a C18 column (Supelcosil LC $18,15 \mathrm{~cm} \times 4.6 \mathrm{~mm}, 5 \mathrm{~mm})$.

\subsubsection{Analyses of Mycotoxins}

The determination of aflatoxins was performed by high performance liquid chromatography (Shidmadzu LC 20AT) on a purified extract and concentrated after derivation with trifluoroacetic acid by adaptation of the AOAC method [14] adapted for this study. The fluorimetric detection was ((RF-10AxL) at wavelengths of $365 \mathrm{~nm}$ and $435 \mathrm{~nm}$, excitation and emission respectively. For the ochratoxin A, the method used was the standard NF EN [15]. The samples were treated with a polyethylene glycol solution and of sodium hydrogencarbonate, then filtered and purified on an immune affinity column. After elution with methanol, ochratoxin A was quantified by high performance liquid chromatography in reverse phase coupled with fluorimetric detection $(\lambda e x=330 \mathrm{~nm}$ and $\lambda$ ém $=460 \mathrm{~nm})$.

\subsubsection{Methodsvalidation}

Validation of the internal test methodswas made according to directive 2001/22/EC for heavymetals, adaptation of the proceduredeveloped by IFREMER of Nantes for histamine and directive 2002/26/EC formycotoxins

Data were expressed as mean \pm standard deviation (SD). Data were analyzed by Anova at $\alpha=0.05$. Mean comparisons were made by the Fisher test and differentiation was considered significant at $\mathrm{p}<0.05$. The STATISCA 7.1 software is used for statistical analysis.

\section{Results and Discussion}

\subsection{Analytical Quality Assurance}

Analyticalresultsobtained on the materialused to validate the methods are presented in Table 1. The coefficients of variation (RSDR) are: 1.756 for $\mathrm{Pb}$; 4.593 for $\mathrm{Hg}$; 4.614 for the $\mathrm{Cd}$ for the repeatability test and 4.468 for the $\mathrm{Pb}$; 4.529 for $\mathrm{Hg}$; 4.809 for $\mathrm{Cd}$ for the reproductivity test.For repeatability tests, 
oncentrations of the standard solutions were respectively $30 \mu \mathrm{l} / \mathrm{L} ; 15 \mathrm{ul} / \mathrm{L} ; 0.8$ $\mu \mathrm{l} / \mathrm{L}$ and $2.5 \mathrm{mg} / \mathrm{L}$ for $\mathrm{Pb}, \mathrm{Hg}, \mathrm{Cd}$ and histamine. For reproductivity tests, concentrations of standard solutions wererespectively $10 \mu \mathrm{l} / \mathrm{l} ; 15 \mu \mathrm{l} / \mathrm{l} ; 0.8 \mu \mathrm{l} / \mathrm{l}$ and $2.5 \mathrm{mg} / \mathrm{L}$ for $\mathrm{Pb}, \mathrm{Hg}$, $\mathrm{Cd}$ and histamine.

For mycotoxins, robustness of the analytical methods was examined and the results obtained are in Table 2.

\subsection{SampleAnalysis}

Mercury, lead, cadmium and histamine were measured in samples of Garba at average concentrations of $0.19 \mathrm{mg} / \mathrm{kg}, 0.19 \mathrm{mg} / \mathrm{kg}, 0.03 \mathrm{mg} / \mathrm{kg}$ and $32.69 \mathrm{mg} / \mathrm{kg}$, respectively (Table 3 ).

The mycotoxins detected in the Garba samples had values ranging from 0.42 $\mu \mathrm{g} / \mathrm{kg}$ (ochratoxin A) to $8.07 \mu \mathrm{g} / \mathrm{kg}$ (Aflatoxin G1) as shown in Table 4 .

Among the detected aflatoxin, B2 aflatoxin was found in only $23.33 \%$ of the samples while aflatoxin B1 and OTA were found in more than half of the samples (Table 5).

\subsection{Discussion}

The present study was undertaken to evaluate the chemical quality of Garba. To

Table 1. Analytical results for $\mathrm{Pb}, \mathrm{Hg}, \mathrm{Cd}$ and histamine for validation methods.

\begin{tabular}{cccccc}
\hline & \multicolumn{5}{c}{$(\% \mathrm{RSD})$} \\
\cline { 2 - 5 } & $\mathrm{Pb}$ & $\mathrm{Hg}$ & $\mathrm{Cd}$ & Histamine \\
\hline Repeatability & 1.756 & 4.593 & 4.614 & 1.35 \\
Reproductivity & 4.468 & 4.529 & 4.809 & 4.07 \\
\hline
\end{tabular}

Table 2. Analyticalresults for mycotoxins for validation Methods.

\begin{tabular}{|c|c|c|c|c|c|c|c|}
\hline & & $\begin{array}{c}\text { Limits of } \\
\text { detection } \\
(\mu \mathrm{g} / \mathrm{Kg})\end{array}$ & $\begin{array}{c}\text { Limits of } \\
\text { quantification } \\
(\mu \mathrm{g} / \mathrm{Kg})\end{array}$ & $\begin{array}{c}\text { Accuracy } \\
(\%)\end{array}$ & $\begin{array}{c}\text { Reliability } \\
(\%)\end{array}$ & $\begin{array}{c}\text { Efficiency } \\
(\%)\end{array}$ & $\begin{array}{c}\text { Standard } \\
\text { deviations } \\
(\%)\end{array}$ \\
\hline Ochratox & & 0.05000 & 0.2000 & 5.67 & 0.26 & 86.0 & 6.01 \\
\hline \multirow{4}{*}{ Aflatoxin } & B1 & 0.00564 & 0.0188 & 6.01 & 1.80 & 93.0 & 3.01 \\
\hline & B2 & 0.00151 & 0.0050 & 6.01 & 1.80 & 92.5 & 3.01 \\
\hline & G1 & 0.00136 & 0.0045 & 6.01 & 1.80 & 91.4 & 3.01 \\
\hline & G2 & 0.00143 & 0.0047 & 6.01 & 1.80 & 90.7 & 3.01 \\
\hline
\end{tabular}

Table 3. Average levels of heavy metals and histamine in Garba samples.

\begin{tabular}{cccc}
\hline Parameters $(\mathrm{mg} / \mathrm{kg})$ & Minimal Value & Maximal Value & Average Value \\
\hline Mercury & 0.01 & 0.40 & $0.19 \pm 0.29$ \\
Lead & 0.03 & 0.35 & $0.19 \pm 0.20$ \\
Cadmium & 0.01 & 0.04 & $0.03 \pm 0.05$ \\
Histamine & 13.61 & 66.10 & $32.69 \pm 9.77$ \\
\hline
\end{tabular}


Table 4. Average levels of mycotoxins in Garba.

\begin{tabular}{cccc}
\hline Parameters $(\mu \mathrm{g} / \mathrm{kg})$ & Minimal Value & Maximal Value & Average Value \\
\hline Aflatoxin B1 & 0.02 & 35.78 & $3.44 \pm 8.11$ \\
Aflatoxin B2 & 0.10 & 23.95 & $1.90 \pm 5.68$ \\
Aflatoxin G1 & 0.56 & 69.32 & $8.07 \pm 16.95$ \\
Aflatoxin G2 & 0.04 & 13.33 & $0.56 \pm 2.43$ \\
Aflatoxin total & 0.01 & 39.85 & $13.95 \pm 17.96$ \\
Ochratoxin A & 0.06 & 1.83 & $0.42 \pm 0.56$ \\
\hline
\end{tabular}

Table 5. Samples of positive Garba to mark mycotoxins.

\begin{tabular}{cccc}
\hline Mycotoxins & $\begin{array}{c}\text { Number of } \\
\text { positive samples }\end{array}$ & Frequency (\%) & $\begin{array}{c}\text { Number of positive samples } \\
\text { exceeding the authorized limit }\end{array}$ \\
\hline Aflatoxin B1 * & 170 & 56.60 & 40 \\
Aflatoxin B2 & 70 & 23.33 & - \\
Aflatoxin G1 & 140 & 46.66 & - \\
Aflatoxin G2 & 120 & 40.00 & 107 \\
Aflatoxins totals $* *$ & 290 & 96.67 & - \\
Ochratoxin A & 190 & 63.30 & - \\
\hline
\end{tabular}

${ }^{*} \mu \mu \mathrm{g} / \mathrm{kg}$ Limit Value of the authorized Aflatoxin B1 (CE/1881/2006), ${ }^{* *} 15 \mu \mathrm{g} / \mathrm{kg}$ Limit Value of the total authorized Aflatoxin.

achieve the purpose, chemical molecules were investigated in several samples of Garba. The chemical analyzes of the samples of Garba showed that it contains heavy metals, but also histamine as well as mycotoxins. At the level of heavy metals, namely lead, cadmium and mercury, average proportions obtained were, however, lower than the recommended limits $(1 \mathrm{mg} / \mathrm{kg}$ for mercury, $0.3 \mathrm{mg} / \mathrm{kg}$ for lead and $0.1 \mathrm{mg} / \mathrm{kg}$ for cadmium) in accordance with standard CE 1881 [16]. The average mercury content in the Garba samples was indeed $0.19 \mathrm{mg} / \mathrm{kg}$ against $1 \mathrm{mg} / \mathrm{kg}$ representing the limit value of this toxic in fish, recognized as the main source of food contamination due to mercury. Garba being a fish-containing food (tuna), the presence of mercury in the Garba could be attributable to this component. Fish, including tuna, is indeed recognized for his stacking character for mercury, the latter tend to remain stored in different organs [17]. In this regard, several authors have reported the presence of mercury in fish of the Scombridae family [18] [19] [20].

The detected lead and cadmium in the samples analyzed could in turn come from several Garba components such as fish and vegetables. Indeed, like fish, vegetables such as onions and tomatoes are also frequently involved in the contamination due to these two metals [21] [22] [23]. The absence of a limit value for lead in Garba does not give any indication of the quality of the Garba dish for this metal. It should, nevertheless, be noted that some lead values obtained in the Garba samples are relatively high $(0.34$ and $0.35 \mathrm{mg} / \mathrm{kg})$ compared to the fish 
limits values. At the cadmium level, the mean value of $0.03 \mathrm{mg} / \mathrm{kg}$, was small compared to the limit value of $0.1 \mathrm{mg} / \mathrm{kg}$ applied to potato that could be compared to cassava, which is the raw material serving for the production of the main ingredient of the Garba namely attiéké. Based on this comparison, the level of cadmium contamination Garba appeared to be acceptable.

The mean levels of lead and cadmium found in the Garba samples were below the tolerable limit values that are respectively 0.19 and $0.03 \mathrm{mg} / \mathrm{kg}$. However, among all samples analyzed, some contained values above these limits. Garba consumption containing high levels of lead and cadmium could cause physiological disorders among consumers. Lead is recognized as responsible for lead poisoning, an acute or chronic professional or domestic poisoning. It is a serious disease that can affect humans and particularly children and pregnant women [24]. Conversely, cadmium causes lung problems if inhaled. It can be very harmful to low concentration when consumed over a long period [25].

Concerning histamine, its content in the analyzed samples $(66.1 \mathrm{mg} / \mathrm{kg}) \mathrm{did}$ not exceed the tolerated limit value in tuna $(100 \mathrm{mg} / \mathrm{kg})$. Potential sources of this biogenic amine in the Garba could be fish, vegetables but also attiéké. Many authors have indeed shown the presence of histamine in tuna [26] [27] [28] and tomato [29]. Moreover, attiéké could be implicated because of its production process mainly based on fermentation. It has indeed been shown that many fermented foods (cheese, drinks, sausages and vegetables) contained histamine and their consumption may have had toxicological consequences [30] [31].

All the current mycotoxins in the samples were detected, suggesting a fungal contamination of this meal. Several studies have already mentioned the presence of aflatoxins in food. It was the case of Muthomi et al. [32], Kang'e the and Lang' at [33], Offifahand Adesiyun [34] and Lewis et al. [35] that have detected the presence of aflatoxins in pasteurized products, cheese, peanut butter, alcoholic beverages from cereals, foods for infants and maize. In the current study, more than half of the samples contained aflatoxin B1. This mycotoxin is deemed extremely dangerous to humans and is responsible for liver cancer. Indeed, aflatoxin is the basis of the acute destruction of the liver and cirrhosis of the liver, and the development of tumors or other genetic defects [36] [37] [38].

The aflatoxin B1 contents of the Garba samples were between 0.02 and 35.78 $\mu \mathrm{g} / \mathrm{kg}$. The maximum value for the aflatoxinB1 found in samples of Garba was much higher than the regulatory limit value of $8 \mu \mathrm{g} / \mathrm{kg}$ [16]. Ingestion of high aflatoxin B1 could cause, as well, liver cancer [39] [40] and growth delay in children [41]. Thus the consumption of Garba could be source of disease among consumers. The presence of aflatoxin B1 in the Garba could probably be due to the attiéké. Attiéké contains a relatively high humidity, over 40\%, [9] [42] [43] and is expected to be contaminated with mold. Previous studies have already mentioned the presence of mold in attiéké [44] [45] [46].

Acceptable levels of mycotoxins in food are not regulated in Ivory Coast. However, in countries or in within the European Community where they are, 
they vary depending on the type of mycotoxin and the food. Under the EU Regulation [16], which defines the maximum permissible quantities of mycotoxins in foodstuffs, the highest values are $15 \mu \mathrm{g} / \mathrm{kg}$ for the sum of the 4 aflatoxins, against $8 \mu \mathrm{g} / \mathrm{kg}$ for aflatoxin B1. Our findings are disagreeing with those of [47] [48] that have not detected the presence of aflatoxins (B1, B2, G1 and G2) in analyzed samples of attiéké during their Experiments. In our study, only thirty Garba samples (10\%) were completely free of these toxins.

The level of aflatoxin B1 in the analyzed samples were between 0.02 and 35.78 $\mu \mathrm{g} / \mathrm{kg}$ with an average value of $3.43 \mu \mathrm{g} / \mathrm{kg}$. Forty Garba samples $(23.52 \%)$ contaminated with mycotoxins had values that exceeded the regulatory limit (8 $\mu \mathrm{g} / \mathrm{kg}$ ), which could be dangerous for Garba consumers. In France, according to the 2001-2004 Monitoring Plan, the average concentrations of aflatoxins cereals are between 0.2 and $0.3 \mu \mathrm{g} / \mathrm{kg}$. This includes only three products (rice, semolina and maize flour) where the concentrations of aflatoxin B1 exceed the regulatory limit $(2 \mu \mathrm{g} / \mathrm{kg})$. The average of aflatoxin B1 in all the food was 5.31 $\mu \mathrm{g} / \mathrm{kg}[49]$.

In relation to the total aflatoxin content (37\%) the analyzed samples show significant levels exceeding the regulatory limit $(15 \mu \mathrm{g} / \mathrm{kg})$. Furthermore, the average value of the sum of the aflatoxins in the Garba $(39.27 \mu \mathrm{g} / \mathrm{kg})$ was higher compared to the fixed limit value of $15 \mu \mathrm{g} / \mathrm{kg}$. This situation suggests that Garba could be a dangerous food for the health. This was as well reported for other foods containing high levels of aflatoxin [50]. They have shown that peanuts in Morocco were highly contaminated with mycotoxins, while they had a total aflatoxin content of $850 \mu \mathrm{g} / \mathrm{kg}$.

The authorized quantities of OTA in food ranged from $2 \mu \mathrm{g} / \mathrm{kg}$ to $10 \mu \mathrm{g} / \mathrm{kg}$ [16] depending on the nature of the food. The amounts of OTA determined in the Garba samples did not exceeded $2 \mu \mathrm{g} / \mathrm{kg}$. This was as well reported by [47] in a similar experiment where traces of OTA were not exceeding $0.2 \mu \mathrm{g} / \mathrm{kg}$ in the samples of attiéké. In Côte d'Ivoire, data on OTA vary depending on the nature of the analyzed products. Dano et al., [51] reported that $63 \%$ of the coffees analyzed in their experiments, contained a value of OTA above $20 \mu \mathrm{g} / \mathrm{kg}$ with a mean value of $31.3 \mu \mathrm{g} / \mathrm{kg}$. In maize, Sangaré et al. [52] evaluated the OTA between $3 \mu \mathrm{g} / \mathrm{kg}$ and $1738 \mu \mathrm{g} / \mathrm{kg}$ against $119 \mu \mathrm{g} / \mathrm{kg}$ in the same matrix [53]. According to a study conducted between 1998 and 2002, millet, rice and peanuts contained contents between 17 and $204 \mu \mathrm{g} / \mathrm{kg}$, between 9 and $92 \mu \mathrm{g} / \mathrm{kg}$ and 0.6 to $64 \mu \mathrm{g} / \mathrm{kg}$ respectively [52].

Elsewhere in Morocco, Tantaoui-Elaraki et al. [50] reported on the outcome of their experiments, that a significant proportion of barley samples (36\%) contained no OTA. For the samples containing OTA, those were evaluated between 1.13 and $2.83 \mu \mathrm{g} / \mathrm{kg}$. The presence of OTA in particular, and in general those of mycotoxins in these foods could be explained by their high humidity, favorable condition for the development of molds such as Aspergillus, Penicillium and Fusarium responsible for the production of these toxins [54]. 


\section{Conclusion}

Ensuring food safety requires due attention during harvest, transport, processing, storage and finally during food preparation and storage by consumers. The Garba Samples analyzed contained mycotoxins and heavy metals. If heavy metals and histamine were found at low levels not exceeding the recommended threshold values by the Food Standards, mycotoxins were detected at levels beyond the recommended limits. The consumption of Garba could be a source of food poisoning for consumers. Application of sound policies and regulations should be advocated in Côte d'Ivoire to ensure public health and safety. Awareness campaigns and training of the Garba vendors in hygiene and a better regulation of this sector by the competent authorities are required.

\section{References}

[1] FAO (1989) Street Foods. A Summary of FAO Studies and Other Activities Relating to Street Foods. FAO, Rome.

[2] Ekanem, E.O. (1998) The Street Food Trade in Africa: Safety and Socio-Environmental Issues. Food Control, 9, 211-215.

[3] FAO (1997) Rapport d'une réunion technique de la FAO sur l'alimentation de rue. Calcutta, Inde. 6-9 Novembre 1995. FAO, Rome, 1-4.

[4] WHO/FAO (2010) Mesures de base pour améliorer la sécurité sanitaire des aliments vendus sur la voie publique. Sécurité sanitaire des aliments vendus dans la rue. Note d'information INFOSAN no. 3/2010; (INFOSAN) 30 juin 2010. Réseau international des autorités de sécurité sanitaire des aliments.

[5] WHO (2015) Food Safety: What You Should Know. World Health Day: 7 April 2015. World Health Organization.

[6] Rane, S. (2011) Street Vended Food in Developing World: Hazard Analyses. Indian Journal of Microbiology, 51, 100-106.

[7] Hanashiro, A., Morita, M., Matté, G.R., Matté, M.H. and Torres, E.A.F.S. (2005) Microbiological Quality of Selected Street Foods from a Restricted Area of São Paulo City, Brazil. Food Control, 16, 439-444.

[8] Ghosh, M., Wahi, S., Kumar, M. and Ganguli, A. (2007) Prevalence of Enterotoxigenic Staphylococcus aureus and Shigella spp. in Some Raw Street Vended Indian Food. International Journal Environmental Health Research, 17, 151-156.

[9] Gbané, M., Coulibaly, A., Niaba, K.P.V. and Adou, M. (2012) Composition physico-chimique de deux mets de rue (Le plat d'attiéké et le garba) vendus à Abidjan (Côte d'Ivoire). Afrique biomédicale, 17, No. 3.

[10] Cofrac (2008) Guide technique d'accréditation, dosage des mycotoxines et des phycotoxines dans les denrées alimentaires destinées à l'homme et les animaux. Doc LABGTA 21.

[11] AOAC (2000) Official Methods of Analysis, Metals and Others, Method 971.21; Mercury in Food, Flamless Atomic Absorption Spectrophotometric Method, Chapiter 9, p. 35.

[12] AOAC (2003) Official Methods of Analysis, Metals and Others, Method 999.10; Lead, Cadmium, Zinc, Copper, and Iron in Foods. Atomic Absorption Spectrophotometry after Microwave Digestion. Chapter 9, p. 46.

[13] Ifremer (2008) Les principales méthodes de dosage de l'histamine. Fiche réalisée 
pour Bibliomer, et le centre veille des produits aquatiques.

http://www.bibliomer.com/

http://veilleproduitsaquatiques.com/

[14] ISO 16050-2003: Produits alimentaire-dosage de l'aflatoxine B1 et détermination de la teneur en aflatoxine B1B2G1et G2 dans les céréales, les fruits à coques et les produits dérivés. Méthode Chromatographique liquide à haute performance.

[15] NF EN 14133-2004: Produits alimentaires-Dosage de l'ochratoxine A dans le vin et la bière-méthode HPLC avec colonne d'immuno affinité nettoyage.

[16] Commission Européenne (CE) No 1881/2006: De la commission du 19 Décembre 2006 portant fixation de teneurs maximales pour certains contaminants dans les denrées alimentaires. Journal Officiel de P Union Européenne.

[17] Kojadinovic, J., Potier, M., Le Corre, M., Cosson, R. and Bustamante, P. (2007) Bioaccumulation of Trace Elements in Pelagic Fish from the Western Indian. Ocean Environmental Pollution, 146, 548-566.

[18] Licata, P., Drombetta, D., Cristani, M., Naccari, C., Martino, D., Calo, M. and Naccari, F. (2005) Heavy Metals in Liver and Muscle of Bluefin Tuna (Thunnus thynnus) Caught in the Straits of Messina (Sicily, Italy). Environmental Monitoring and Assessment, 107, 239-248. https://doi.org/10.1007/s10661-005-2382-1

[19] Koffi, K.M., Biego, G.H., Ake-Assi, Y. and Agbo, N.G. (2007) Estimation de l'apport en mercure à partir de la consommation depoisson en Côte d'Ivoire. Science et Nature, 4, 171-177.

[20] Sivaperumal, P., Sankar, T. and Viswanathan Nair, P.G. (2007) Heavy Metal Concentrations in Fish, Shellfish and Fish Products from Internal Markets of India vis-a-vis International Standards. Food Chemistry, 102, 612-620. https://doi.org/10.1016/j.foodchem.2006.05.041

[21] Boisset, M. and Cumont, G. (1996) Plomb, cadmium et mercure dans l'alimentation. Evaluation et gestion du risque. Conseil supérieur d'hygiène de France, section de l'alimentation et la nutrition. Direction générale de la santé et affaires sociales.

[22] Benajiba, N., Frigola, A., Frasquet, I., Borghos, F. and Aguenaou, H., (2007) Quantification par la technique de polarographie de la vitamine $\mathrm{C}$, du zinc, du cuivre, du cadmium et du plomb dans les fruits et légumes frais dans la région du Nord-ouest du Maroc. Biomatec Echo, 2, 63-69.

[23] Sipter, E., Rózsa, E., Gruiz, K., Tátrai, E. and Morvai, V. (2008) Site-Specific Risk Assessment in Contaminated Vegetable Gardens. Chemosphere, 71, 1301-1307.

[24] Ziegler, E., Edwards, B., Jensen, R., Mahaffey, K. and Fomon, S. (1978) Absorption and Retention of Lead by Infants. Pediatric Research, 12, 29-34. https://doi.org/10.1203/00006450-197801000-00008

[25] Tuzen, M. and Soylak, M. (2007) Determination of Trace Metals in Canned Fish Marketed in Turkey. Food Chemistry, 101, 1378-1382. https://doi.org/10.1016/j.foodchem.2006.03.044

[26] Tsai, Y., Lin, C., Chang, S., Chen, H., Kung, H., Wei, C. and Hwang, D. (2005) Occurrence of Histamine and Histamine-Forming Bacteria in Salted Mackerel in Taiwan. Food Microbiology, 22, 461-467. https://doi.org/10.1016/j.fm.2004.11.003

[27] Tsai, Y., Lin, C., Chang, S., Chen, H., Kung, H., Wei, C. and Hwang, D. (2005) Histamine Production by Enterobacter aerogenes in Sailfish and Milkfish at Various Storage Temperatures. Journal of Food Protection, 68, 1690-1695.

https://doi.org/10.4315/0362-028X-68.8.1690 
[28] Chen, H., Kung, H., Chen, W., Lin, W., et al. (2008) Determination of Histamine and Histamine-Forming Bacteria in Tuna Dumpling Implicated in a Food-Borne Poisoning. Food Chemistry, 106, 612-618.

[29] Duflos, G. (2009) Le risque histamine dans les produits de la mer. http://www.academie-veterinaire-defrance.org

[30] Magwamba, C., Matsheka, M.I., Mpuchane, S. and Gashe, B.A. (2010) Detection and Quantification of Biogenic Amines in Fermented Food Products Sold in Botswana. Journal Food Protection, 73, 1703-1708. https://doi.org/10.4315/0362-028X-73.9.1703

[31] Spano, G., Russo, P., Lonvaud-Funel, A., Lucas, P., Alexandre, H., Grandvalet, C., Coton, E., Coton, M., Barnavon, L., Bach, B., Rattray, F., Bunte, A., Magni, C., Ladero, V., Alvarez, M., Fernandez, M., Lopez, P., de Palencia, P.F., Corbi, A., Trip, H. and Lolkema, J.S. (2010) Biogenic Amines in Fermented Foods. European Journal of Clinical Nutrition, 64, S95-S100. https://doi.org/10.1038/ejen.2010.218

[32] Muthomi, J.W., Mureithi, B.K., Chemining'wa, G.N.,Gathumbi, J.K. and Mutit, E.W. (2012) Aspergillus Species and Aflatoxin b1 in Soil, Maize Grain and Flour Samples from Semi-Arid and Humid Regions of Kenya. International Journal of AgriScience, 2, 22-34.

[33] Kang'ethe, E.K. and Lang'at, A.K. (2009) Aflatoxin B1 and M1 Contamination of Animal Feeds and Milk from Urban Centers in Kenya. African Health Science, 9, 218-226.

[34] Offifah, N. and Adesiyun, A. (2007) Occurrence of Aflatoxins in Peanuts, Milk, and Animal Feed in Trinidad. Journal of Food Protection, 70, 771-775. https://doi.org/10.4315/0362-028X-70.3.771

[35] Lewis, L., Onsongo, M., Njapau, H., Schurz-Rogers, H., Luber, G., Kieszak, S., Nyamongo, J., Backer, L., Dahiye, A.M., Misore, A., DeCock, K., Rubin, C. and The Kenya Aflatoxicosis Investigation Group (2005) Aflatoxin Contamination of Commercial Maize Products during an Outbreak of Acute Aflatoxicosis in Eastern and Central Kenya. Environmental Health Perspectives, 113, 1763-1767. https://doi.org/10.1289/ehp.7998

[36] Bhat, R.V. and Vasanthi, S. (2003) Sécurité alimentaire et aliment sain commerce: Mycotoxine, Aliment sain dans les pays en voie de développement. Focus 10 brief 3 to 17 .

[37] Who and $c D c$ (2005) Stratégies de la santé publique visant à prévenir l'exposition aux aflatoxines. Rapport de groupe de travail pour l'atelier international sur les Mycotoxines, Genève, Juillet 2005.

[38] Wild, C. and Gong, Y. (2010) Mycotoxins and Human Disease: A Largely Ignored Global Heath Issue. Carcinogenesis, 31, 71-82.

https://doi.org/10.1093/carcin/bgp264

[39] Parkin, D.M., Bray, F., Ferlay, J. and Pisani, P. (2002) Global Cancer Statistics, 2002. CA: A Cancer Journal for Clinicians, 55, 74-108. https://doi.org/10.3322/canjclin.55.2.74

[40] Kirk, G.D., Bah, E. and Montesano, R. (2006) Molecular Epidemiology of Human Liver Cancer: Insights into Etiology, Pathogenesis and Prevention from The Gambia, West Africa. Carcinogenesis, 27, 2070-2082. https://doi.org/10.1093/carcin/bgl060

[41] Okoth, S.A. and Ohingo, M. (2004) Dietary Aflatoxin Exposure and Impaired Growth in Young Children from Kisumu, Kenya: Cross Sectional Study. African Journal of Health Sciences, 11, 43-54. 
[42] Sotomey, M., Ategbo, E.A., Mitchikpe, E. and Gutierrez, M.L. (2001) Innovations et diffusion de produits alimentaires en Afrique: L'attiéké au Bénin. Analyse Physico-chimique de I Attiéké Ivoirienne, 55-57.

[43] Krabi, E.R., Assamoi, A.A., Ehon, A.F., Bréhima, D., Niamké, L.S. and Thonart, P. (2015) Production d'attiéké (couscous à base de manioc fermenté) dans la ville d'Abidjan. European Scientific Journal, 11, 1857-1881.

[44] Darboux, J.G. and Ahounou, J.L. (2004) Stockage des cossettes de manioc: Tests comparatifs sur les emballages et structure de stockage. In: Fandohan, P., Koudandé, D., Houssou, P. and Megnanglo, M., Eds., Actes de P Atelier scientifique post-récolte PADSA/PTAA, Bohicon, Bénin.

[45] Darman, R.D., Ngang, J.J.E. and Etoa, F.X. (2007) Qualité nutritive, toxicologique et hygiénique de certains produits derivés du manioc consommés au Cameroun. In: Amani, G., et al., Eds., Actes du ler Atelier international sur les potentialités à la transformation du manioc en Afrique de l'Ouest, 4-7 Juin 2007, Abidjan, Côte d'Ivoire, 223-227.

[46] Kouamé, A.K., Djéni, T.N., N’Guessan, F.N. and Djé, M.K. (2012) Postprocessing Microflora of Commercial Attieke (a Fermented Cassava Product) Produced in the South of Côte d'Ivoire. Letters in Applied Microbiology, 56, 44-50. https://doi.org/10.1111/lam.12014

[47] Kastner, S., Kandler, H., Bleisch, M., Lacroix, C. and Meile, L. (2010) Dépistage de mycotoxines dans l'inoculum utilisé pour la production d'attiéké, un produit traditionnel de manioc ivoirien. Lebensmittel-Wissenschaft \& Technologie, 43, 1160-1163.

[48] Guira, F. (2013) Evaluation des valeurs nutritive et sanitaire d'attiéké issu de différentes pâtes de manioc importées ou produites localement à partir de différents ferments. Mémoire DEA, Université de Ouagadougou, 79 p.

[49] Afssa: Agence Française de sécurité sanitaire des aliments (2009) Évaluation des risques liés à la présence de mycotoxines dans les chaînes alimentaires humaine et animale, rapport final.

[50] Tantaoui-Elaraki, A., Benabdellah, L., Majdi, M., Elalaoui, M.R. and Dahmani, A., (1994) Recherche des mycotoxines dans les denrées alimentaires distribuées au Maroc. Actes des Instituts Agronomique et Vétérinaire, 14, 11-16.

[51] Dano, D.S., Manda, P., Kouadio, J.H., Dembélé, A.A. and Diakité, A, (2008) Etude de l'incidence de la torréfaction appliquée au café vert sur la réduction du taux de l'ochratoxine A (OTA) dans le produit fini. European Journal of Scientific Research, 26, 393-401.

[52] Sangare-Tigori, B., Moukha, S., Kouadio, H.J., Betbeder, A.-M., Dano, D.S. and Creppy, E.E. (2006) Co-Occurrence of Aflatoxin $\mathrm{B}_{1}$, Fumonisin $\mathrm{B}_{1}$, Ochratoxin A and Zearalenone in Cereals and Peanuts from Côte d'Ivoire. Food Additives and Contaminants, 23, 1000-1007. https://doi.org/10.1080/02652030500415686

[53] Kouadio, I.A., Koffi, L.B., Nemlin, J.G. and Dosso, M.B. (2012) Effect of Robusta (Coffea canephora P.) Coffee Cherries Quantity Put Out for Sun Drying on Contamination by Fungi and Ochratoxin A (OTA) under Tropical Humid Zone (Côte d'Ivoire). Food and Chemical Toxicology, 50, 1969-1979. https://doi.org/10.1016/j.fct.2012.03.042

[54] Le Bars, J. and Le Bars, P. (2000) Mycotoxigenesis in Grains Application to Mycotoxic Prevention in Coffee. In: Sera, T., Soccol, C.R., Pandey, A. and Roussos, S., Eds., Coffee Biotechnology and Quality, Kluwer, Dordrecht, 355-368.

https://doi.org/10.1007/978-94-017-1068-8_33 